ith the general appearance and ctions of a thrasher fly down to the round and back up on the fence ong the pasture. As we got closer saw that it had color markings mewhat similar to a shrike and called back to the bird watcher, What have we here?" "A shrike", e said seeing the color, but on ticing the thrasher-like form and ight her interest was aroused as ly that of a bird watcher can be. he bird flew into a clump of willows ong the fence. We got out and ent over, but it appeared to be a y bird and quickly flew over to a earby bluff. We went into the paste and drove toward the bluff, but fore we could get out of the car e bird had moved to another bluff. argaret suspected it might be a ockingbird (and hoped it would ) but also thought it could be a ownsend's Solitaire. Out came the rd book for a study of fieldmarks fore we continued the chase. But as we lost the bird at the next bluff ad had to be content to continue $r$ drive ending with a picnic supper ong a prairie trail near the Arm alley. Before we left the pasture e saw a Great Horned Owl and und its downy young in a nest in hich I had banded Swainson's awks for Stuart Houston one year.

As we returned home to do the ening chores we were quite surized to spot the same bird we had llowed earlier and along the same fence. This time it proved much more co-operative, and as Margaret and I got out to get a better view it moved up and down the fence and finally into the willow clump where it stayed while we approached - one on each side. Here it stayed and tried to hide among the branches and leaves while we fought off great hordes of mosquitoes and observed it at a distance of not over ten feet for some fifteen minutes. Those minutes seemed like hours as at times the mosquitoes almost make you yell, but there was no way to get out of it - a bird watcher will go through anything to establish beyond the shadow of a doubt the definite and accurate identity of a new species, and I had to go along! We established to our satisfaction that this grey and white thrasher-like bird with the white on wings and tail (but no black mask like the shrike's) was a Mockingbird.

No "seers", I haven't become a "watcher" even though I did get up early and tag along with the watchers at Cypress Hills. I had no luck there even of "seeing" some of the new species of small birds the watchers were finding. However, when looking over the countryside on the way out to Cypress Lake I did see some Sage Grouse which I think escaped many of the watchers. We also saw some fine scenery, and it will be some time before I forget the view from Bald Butte.

\title{
Strictly for the Birds
}

ITOR'S NOTE: Last summer Mr. Wright interviewed Maurice Street, a friend of his if $\mathrm{g}$ standing who took an interest in him when he was going to high school in Nipawin, and ouraged him to becoma a bird watcher and bander. We are pleased to publish Mr. Wright's ort of the interview because of the encouragement it will give all aspiring birdmen.

"STRICTLY FOR THE BIRDS" is expression that usually carries rtain insulting implications. But it $s$ a very different and appropriate aning for Maurice Street of Nipin. Mr. Street is a slim, balding in with warm eyes and a contagis laugh who obviously enjoys life $d$ is accepted as one of Saskatewan's top ornithologists. He's rictly for the birds" and the birds strictly for him!
How did this remarkable bird watcher and bander get his start? Here are his own words. "Well, in 1922 I got my first bird book. It was Chapman's Land Birds East of the Rockies. And at that time Mr. Lawrence of Winnipeg had started his Chickadee Notes (Winnipeg - Free Press), and I began reading. I was twelve years old. I was on the farm at that time and then I moved into town (Tisdale) and I got acquainted 
with Mr. Van Blaricom. I borrowed his field glasses and he showed me a a few of his bird books and made things a little more interesting for me."

What sort of bird watching was the young ornithologist doing? "When you're starting out from scratch that way you've just got to puzzle out every bird you see, because there's no one out there to tell you. You just find these things out for yourself. You see a bird and you don't know what it is and you start looking in the bird book for it and finally you find it. And you get more proficient as you go along." Mr. Van Blaricom put up a prize for the best migration list compiled by a Tisdale youngster and young Maurice took the prize several times. He had been keeping careful records before this, however. Were there any birds in those days that our ornithologist doesn't see now? "No. We see birds now that we didn't see in those days."

How does a young fellow get started watching birds? "Being on the farm more or less isolated. my interest was drawn to birds. One highlight I remember after I met Van Blaricom: I saw a Lewis Woodpecker. It was about ' 26 , I guess. It wasn't even in Chapman, because it was a western bird. And I happened to meet Van Blaricom and he was telling me abcut having seen the bird .too. He didn't know what it was either. We went down to his place and looked through all his bird books and we finally found it."

What are some of the most interesting" "finds" in the Street bird list? "A very recent one was a Whip-poorwill. Roy Lanz and I found the nest. We took pictures of it and I wrote an article about the whole deal for The Blue Jay. And then I remember the Indigo Bunting I saw near Armley in 1926. And the blackheaded Grosbeak I saw down on the river flat near Tisdale . . it's a southern bird."

The conversation turned to Nipawin days. "Nipawin is one of the greatest places in the province for a wide variety of warblers. It's right on the dividing line between the coniferous and transition zones, and we have all types of timber here and we also have swamps and lakes. This is one of the most southern places where suitable nesting habitat is available for warblers. The only place the Chestnut-sided Warbler nests here is within sight of the Saskatchewan river. And that goes for the Canada Warbler, too. There must be twenty species of warblers that we see here."

Sparrows abound hereabouts, too. "Our main nesting sparrow that you don't get nesting further south is the White-throat. And we have the Lincoln nesting here, the Clay-coloured, the Chipping and the Leconte's. As far as nesting is concerned, I haven't got too many to find now. Once you find one or two there's no point in going on finding nests unless you're weighing the eggs." Nipawin has fifteen species of sparrows!

"I started banding in 1945. Stuart Houston got me interested in that, and I've banded .... somewhat over ten thousand birds since 1945 . Which is not too many. One thing I'm quite proud of is the fact that I got Billy Matthews interested in it, and at the present time I think he's one of the sharpest birdmen in the province. He has a keen pair of eyes, and not only that, he was a student who had enough initiative to do things for himself and find out things for himself."

The conversation turned to $\mathrm{Mr}$ Street's own personal methods of birc watching. One question that arose was how much a bird 'call had to $d c$ with bird identification. "On the war" blers-I don't have to see them any more. I know them by voice." Know. ing bird calls comes "only through experience." Do bird book descrip. tions of bird calls give any help a all? "No, none what ever."

What equipment should the youn bird watcher have? "Well, the firs thing that I'd recommend getting i Peterson's A Field Guide to the Bird: I wish now that I'd had one of thos when I was young. It doesn't matte where you are-there are birc everywhere, and if you see a bir you've just got to go to hunt unt you can identify it." Bird watches should be keeping regular bird list "Every, time they go for a walk the should record what they see. Lo of times in my younger days whe I was learning these things, I'd see bird when I was out and wouldr. know what it was, but even if didn't write down a description of I would make a mental note of wh 
looked like. Sometimes with some f these rarer birds I wasn't sure unil years later."

How does this top-flight Saskathewan ornithologist go about identfying a bird in the field? "I think ne of the first things to have noticed $s$ the way the bird flew, and if it id alight on a branch, its posture. iirds are quite different in flight. Iou can pretty well tell the differnce between warblers and kinglets, or instance, just in their flight. If he bird was a small bird and the ead appeared large, I'd think first hat it would have been a vireo. If he bird was slim and held its body corizontal to the branch I'd say it vas a warbler. And if it sat quite traight I'd say it was a flycatcher. then the colour pattern. The first hing I'd look for would be the wing ars. About half of the birds have hem and half of them haven't. Then he colour. And the song, as I have nentioned."
What about good power binoculars for bird watching? "Yes, but not too strong a binocular. I think about a $5 \times 50$ or $8 \times 50$ is plenty strong enough. Small-power glasses have a large field of vision and you don't have to hold them as steady, and with birds it's hard to get them in focus with the more powerful glass."

In summing up, Maurice pointed out an old truth about bird watching and every other form of nature study: "If you like watching birds, it doesn't matter where you go or what time of day it is, or whether it's raining or the sun is shining ... there's always something of interest."

Thirty-four years of "something of interest" have made Maurice Street a leader in his field, and a man richly deserving of the reputation of one of Saskatchewan's top ornithologists!

\section{BIRD NOTES}

\section{More Starling Records}

Wm. Niven reports that the first tarlings were seen at SHEHO, Sask. April 16, 1944. Although they arrive arly in the spring (sometimes even head of Crows) and leave late in all, Mr. Niven believes they are not ear-round residents. Never numrous, the Starlings have decreased $n$ the last few years. For several ears, large flocks gathered in the all- 500 or 600 ; but in the last few ears, fall flocks have been small. irst seen dates: April 16, 1944; March 18, 1945; March 15, 1946; March 24, 1947; March 27, 1948; March 31, 1949; April 5, 1950; April , 1951; March 30, 1952; April 6, 1953; April 5, 1954, March 31, 1955; April , 1956; March 16, 1957.

Mrs. J. Hubbard, GRENFELL, saw he first Starling in their district April 3, 1943 near the town of Grenell. Small flocks were seen in Grenell summer and winter for several years after their first appearance. Then, after an interval of a few years with no Starlings, 4-6 were seen March 9, 1957 at a garbage dump along No. 47 Highway near Grenfell.

Miss E. Barker, Regina, has records of Starlings at MILESTONE (MayJune, 1945), at LORLIE (flock of ca. 15 seen June-Oct., 1945, and described to her as wintering 1944-5), at GIBBS (where she came into possession of a female bird Dec. 31, 1948 which is now in her collection of mounted birds), and at REGINA (1949-1956). Interesting Regina dates Feb. 13, 1955, Dec. 12 1955, Dec., 1956 suggest wintering birds.

Mrs. Clem Osborne reports that Starlings have nested at WROXTON, Sask. every year since she moved there in 1951. Every spring, two, four or six birds nest in holes (probably made by woodpeckers) in the overhanging roof. Early spring arrival dates: March 27, 1953; April 5, 1954; March 30, 1955; March 22, 1956; March 25, 1957.

Dora Bardal has seen Starlings only twice at WYNYARD: a small flock several years ago, probably passing through; and a single bird on March 31, 1957, with a flock of grosbeaks. 